\title{
Signals of 20th-century warming from the glaciers in the Central Italian Alps
}

\author{
Manuela Pelfini, ${ }^{1}$ Claudio Smiraglia ${ }^{2}$ \\ ${ }^{1}$ Department of Territory and Environmental Sciences, University of Milan, 20126 Milan, Italy \\ ${ }^{2}$ Department of Earth Sciences, University of Milan, 20133 Milan, Italy
}

\begin{abstract}
The Lombard Alps in the central sector of the Italian Alps are one of the most intensively glacierized regions on the southern side of the chain (about $113 \mathrm{~km}^{2}$ of ice cover). All of the glaciers have been retreating since the beginning of the 20 th century, but the trend is not uniform. Since the 1950s there has been a drop in the percentage of retreating snouts and an increase in stationary and advancing snouts. After 1985 the glaciers in the Lombard Alps began a new recession phase that is still going on. This pattern is consistent with temperature variations in Lombardy in the 20th century. According to data from Sondrio station, four alternating warming and cooling phases can be distinguished in 20th-century warming. The Lombard glaciers well recorded the last three phases, showing evident signs of the 1955-88 cold phase, with a response time of about 20 years, and may be considered good indicators of 20 th-century temperature trends.
\end{abstract}

\section{INTRODUCTION}

Located in the central sector of the Italian Alps, the Lombard Alps represent about one-fifth of the chain's glacier surface area. The total glacier surface area in the Italian Alps is about $540 \mathrm{~km}^{2}$, the Lombard mountain sector having a glacier cover amounting to over $100 \mathrm{~km}^{2}$, including the two largest glaciers in the Italian Alps, the Forni glacier $\left(13 \mathrm{~km}^{2}\right)$ and the Adamello glacier $\left(18 \mathrm{~km}^{2}\right)$ (Fig. 1). Lombardy is the most highly populated and industrialized region in Italy and ranks second in terms of agricultural production. Its glaciers constitute an important resource for irrigation, the production of hydroelectric power and tourism. The importance of thorough knowledge of the extent of the glacial masses and their fluctuations over time is thus very clear. The earliest inventory, by Porro (1925), indicated a total of 147 Lombard glaciers. The Comitato Glaciologico Italiano (1961) found a total of 271, with a total surface area of

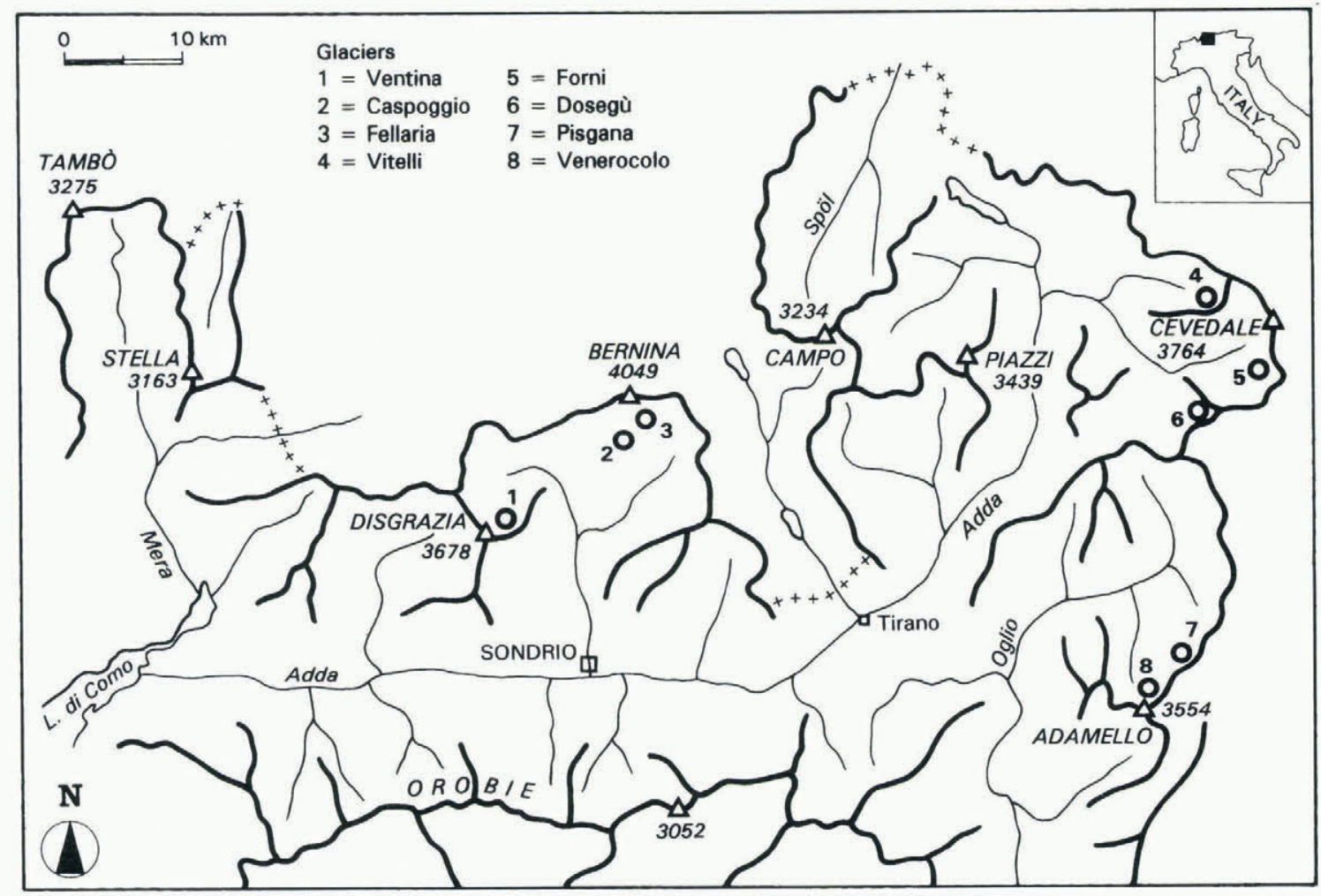

Fig. 1. The Lombard Alps and the glaciers considered in this study. 

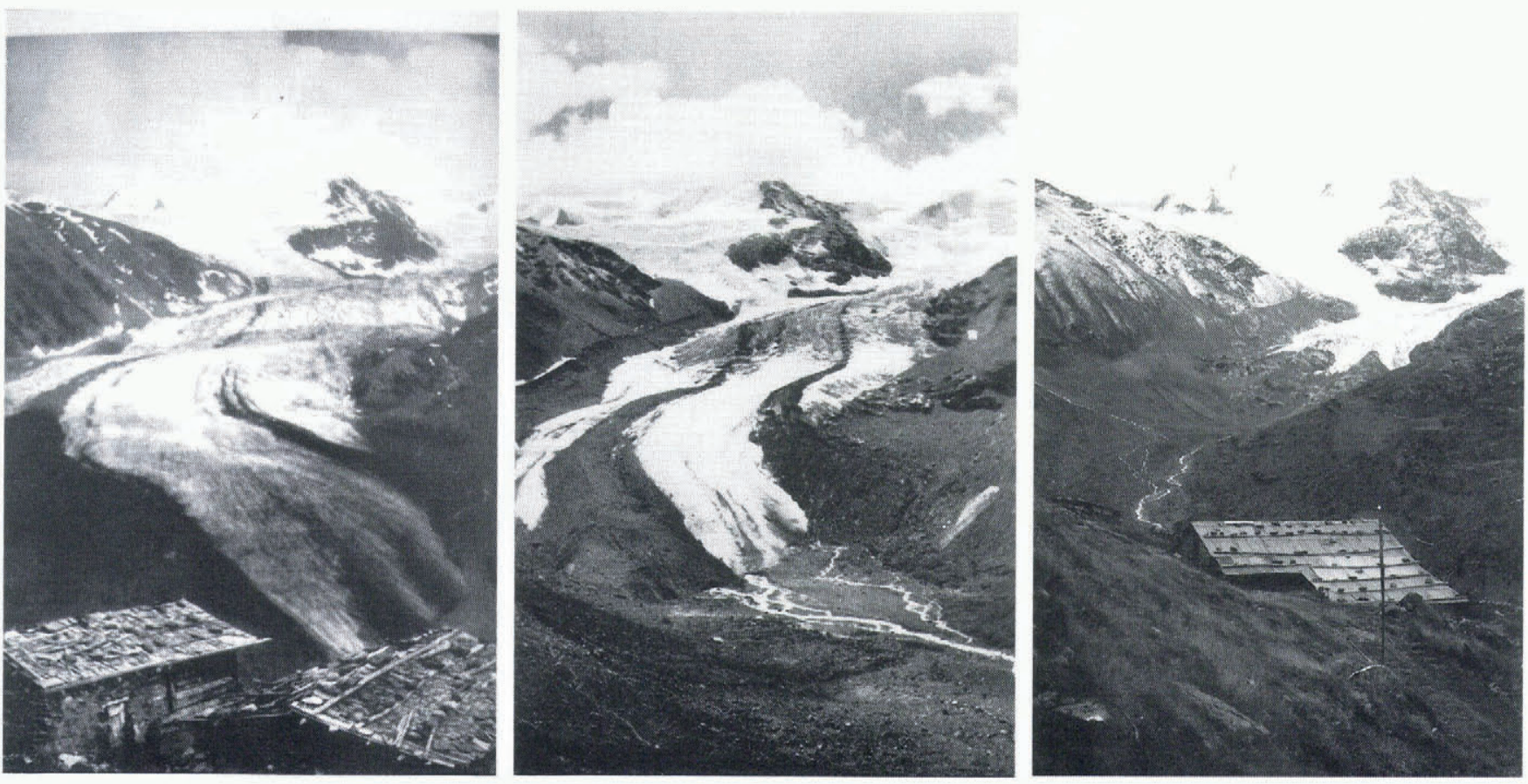

Fig. 2. The Forni glacier (Cevedale Group): probably 1887 photo by V. Sella (left); 1941 photo by A. Desio (centre); 1995 photo by C. Smiraglia (right).

$105.6 \mathrm{~km}^{2}$. In the early $1980 \mathrm{~s}$, as part of the Italian contribution to the World Glacier Inventory, an update was begun (C. Smiraglia and G. Catasta, unpublished information) and yielded a total of 305 glaciers with an overall surface area of $113.65 \mathrm{~km}^{2}$, which then became 304 glaciers and $119.19 \mathrm{~km}^{2}$ in the new inventory of Lombard glaciers by Galluccio and Catasta (1992). It is thought that the slight increase in total glacier surface area observable in the course of the various inventories does not indicate an actual increase in glacierization, but is attributable instead to the improvement of survey and data collection methods. Through the use of various methods, this study has attempted to define the true evolution of the Lombard glaciers in the 20th century, particularly the second part of the century, as well as to ascertain whether these glaciers manifest the same signs of the warming in progress as those demonstrated by glaciers in other Alpine areas (Haeberli, 1990).

\section{THE DATA SET}

The only data available for an analytical reconstruction of the century-old history of Lombard glaciers consist in the measurements of length variations published in various periodicals (Bollettino del Club Alpino Italiano and Bollettino della Società Geografica Italiana until 1913; Bollettino del Comitato

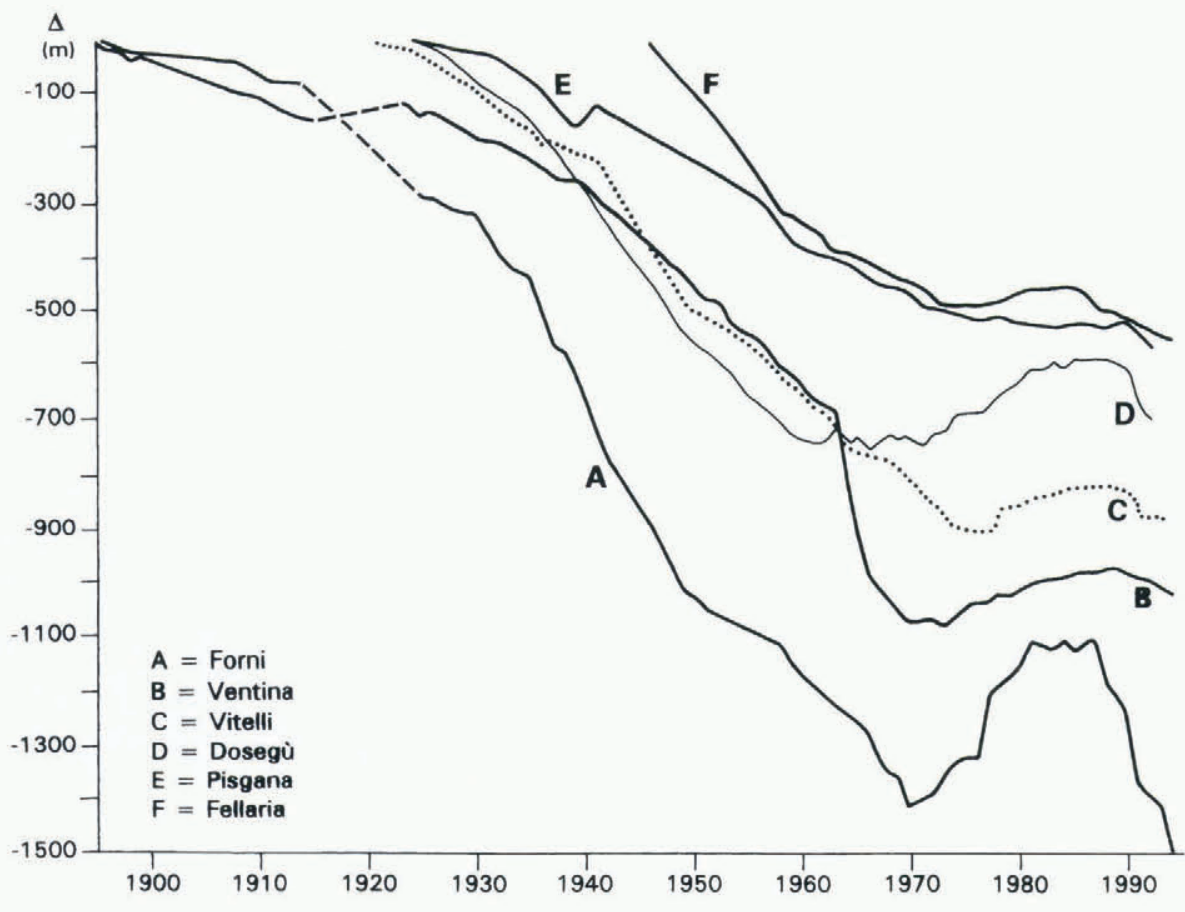

Fig. 3. Length changes for some Lombard glaciers since the beginning of the 20th century. 
Table 1. 20th-century variations of some Lombard glaciers

Ventina (Bernina)

Fellaria (Bernina)

Caspoggio (Bernina)

Vitelli (Cevedale)

Forni (Cevedale)

Dosegù (Cevedale)

Pisgana (Adamello)

Venerocolo (Adamello)

$1923-94$
$1946-94$
$1926-92$
$1921-94$
$1925-94$
$1925-94$
$1924-92$
$1951-92$

1923-94

$1946-94$
$1926-92$

1921-94

$925-94$

1924-92

1951-92

\section{$-898$}

$-564$

$-717$

$-882$

$-1258$

$-697$

$-573$

$-145$

-12.6
-11.7
-10.9
-12.0
-18.2
-10.2
-7.3
-3.5

$-13.1$

$-10.7$

$-9.2$

$-10.7$

$-3.6$

9.0
Glaciologico Italiano, 1914-77; and Geografia Fisica e Dinamica Quaternaria, 1978-94). The first measurement bases were positioned near the fronts of two major valley glaciers (Forni and Ventina) as early as 1895 , and thus for the latter there exist measurement records covering a period of 100 years. Systematic measurements were started by the Comitato Glaciologico Italiano during the 1920s on dozens of glaciers, and were extended even further after 1950. However, almost complete records covering a 70 year period are available for less than ten glaciers, most of which are valley glaciers. Measurements were made using permanent signals with tape or, in recent times, surveying instruments. The first mass balances were calculated after 1985, especially on the Sforzellina glacier, a small cirque glacier for which the data cover a 9 year period (1986/87-1994/95). Other qualitative information available consists of observations on the morphological variations of the glaciers, especially regarding their separation into smaller units.

\section{THE 20TH-GENTURY GLACIER TREND IN LOMBARDY}

The principal evidence of the 20th-century glacier trend in Lombardy consists of a marked decrease in glacier length with substantial reductions in surface area. Considering the two glaciers for which snout variation data are available for almost a 100 year period, it can be observed that between 1895 and 1994 the Forni glacier recorded a length reduction of $1.5 \mathrm{~km}$ (Fig. 2) and the Ventina glacier a reduction of about $1 \mathrm{~km}$. As shown in Figure 3 (curves A and B), the retreat was almost continuous until 1970. There were only little-known advances of the Ventina glacier in the early 1920 s and 1940s and advances of the Forni glacier in the mid-1920s. (For this latter glacier the series lacks measurements for the years 1914-25, and maps, photographic documents and moraine positions have been used to compensate for the lack of data.) A very evident advance phase is distinguishable for both glaciers in the period 1970-85, with advances of about $300 \mathrm{~m}$ for the Forni glacier and $100 \mathrm{~m}$ for the Ventina glacier.

As mentioned above, it was only in the mid-1920s that snout measurements started to be recorded systematically and to include a substantial number of glaciers in the various mountain groups in Lombardy. Analysis of the data reveals total length reductions of about $0.5-1 \mathrm{~km}$ for the main glaciers, the reductions generally being of a larger scale in the first half of the century (Table 1). In fact, in the case of major valley glaciers such as the Forni, Vitelli and Dosegù glaciers, the retreat rate slowed in the second half of the century.

The trend shown by the Lombard glaciers in the second half of the 20th century proves to be more complex and interesting. It appears that there was a slowing of the retreat rate, and in one particular period the records even show a phase of slight advance. The percentages of retreating and advancing Lombard glaciers are indicated in Figure 4 for the period 1950-94. The sample considered ranges from seven glaciers in 1977 to 48 glaciers in 1994. A clear prevalence of retreating glaciers is evident up to 1966. The percentage of stationary and advancing glaciers increases steadily after 1966 and on through to 1978, when advancing glaciers reach $87 \%$ of the total. Thereafter, the advancing phase is more limited until the 1990s, a period in which the percentage of advancing glaciers remains constantly below $10 \%$.

To summarise, three clearly differentiated phases are observable for the Lombard Alps in the second half of the 20th century: (1) an intensive, constant recession phase beginning in the early 1950s; (2) a stationary and advancing phase common to almost the entire area, from the early 1970 s to the end of the 1980s; (3) an intensive recession phase beginning in the early 1990 s and continuing today.

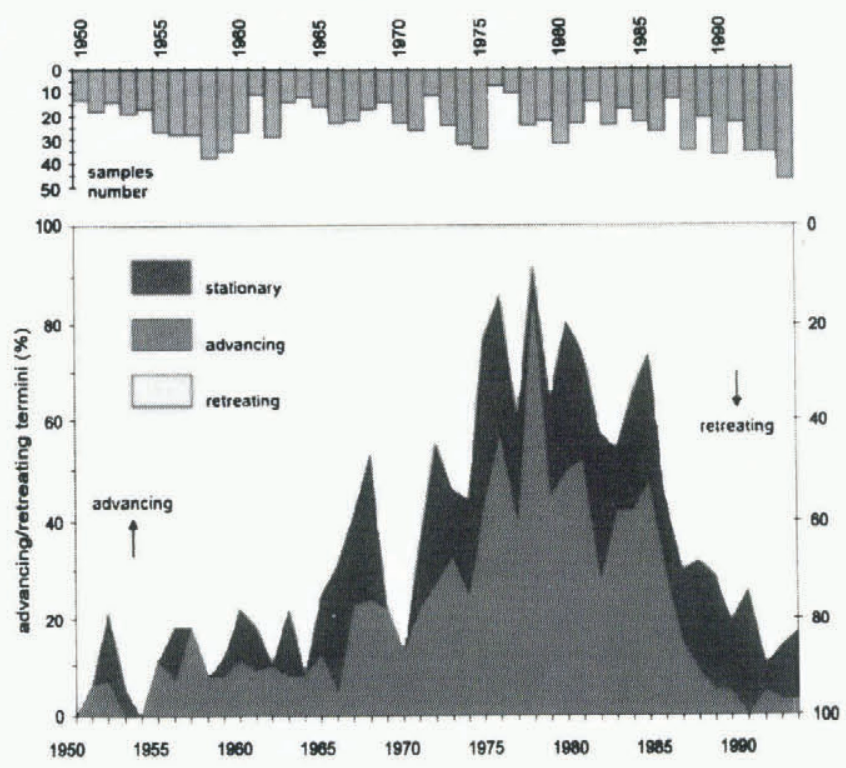

Fig. 4. Glacier fluctuations in the Lombard Alps, 1950-94. Percentages of stationary, advancing and retreating glaciers, relative to the total number of glaciers monitored. 
Evident morphological variations of the glaciers and of the proglacial areas have accompanied the various phases, with a breaking-up of the glaciers into smaller, separate units. For example, until the end of the 1930s the Fellaria glacier, in the Bernina Group, had formed one large compound valley glacier of about $14 \mathrm{~km}^{2}$ on the eastern slope of Pizzo Palù (3906 m)-Pizzo Zupò (3996 m), with two coalescing streams in the terminal section. At present, the two streams are clearly separated and have created two main glaciers, which are almost completely separated (Fellaria west and Fellaria east), as well as two additional smaller units (the Pizzo Varuna and the Cima Fontana glaciers). The same phenomenon occurred with the Scerscen glacier below Pizzo Bernina $(4050 \mathrm{~m})$; the large valley ice stream retreated by more than $1 \mathrm{~km}$ between 1926 and 1940 and broke up into two separate main glaciers (the lower Scerscen and the upper Scerscen) and three smaller glaciers (the Marinelli, Caspoggio and Musella glaciers) (Pelfini and Smiraglia, 1992). Phases 2 and 3 also left distinct morphological evidence. In fact, near the fronts of almost all the glaciers there are frontal and lateral moraines of small dimensions (maximum height: $2-5 \mathrm{~m}$ ). From the mid-1960s to the mid-1980s these moraines were situated in contact with the fronts or even on the outer margins of the glacier tongues and they were therefore still active. In 1995 the moraines were situated $10-20 \mathrm{~m}$ from the frontal margin.

Confirmation of the current recession of the Lombard glaciers can be found in the mass balances which, as mentioned above, have been calculated regularly for somewhat less than a decade. The longest series available is for the Sforzellina glacier, a small cirque glacier in the Cevedale Group. From 1986-87 to 1994 95, the balance was constantly negative and led to a loss of about $3 \times 10^{6} \mathrm{~m}^{3}$ w.e. (Barsanti and Smiraglia, 1994; Barsanti and others, 1996). Specific annual mass balance of -2 to $-3.5 \mathrm{~m}$ w.e. has been measured on the tongues of other glaciers such as the Ventina and Forni glaciers. Additional indications are furnished by variations in the accumulation area ratio (AAR). On the basis of the data collected for the World Glacier Inventory and the new inventory of Lombard glaciers (Galluccio and Catasta, 1992), AAR variations were calculated for the period 1981-90 for 41 glaciers in all the Lombard mountain groups. For 1981 the mean AAR was 0.62 , ranging from 0.49 for the Adamello glacier to 0.74 for the Cevedale glaciers, with glaciers therefore nearing a steady state. For 1990 the mean AAR was 0.27 with maxima of 0.58 in the PiazziCampo Group and minima of 0.23 in the Bernina, Cevedale
Table 2. Deviations $\left({ }^{\circ} \mathrm{C}\right.$ ) of decadal mean annual temperatures at Sondrio station from their total mean $\left(19.9^{\circ} \mathrm{C}\right)$

\begin{tabular}{lc}
\hline Decade & Deviation \\
& \\
\hline $1915-24$ & -0.19 \\
$1925-34$ & +1.21 \\
$1935-44$ & +0.21 \\
$1945-54$ & +0.31 \\
$1955-64$ & 0.59 \\
$1965-74$ & -0.63 \\
$1975-84$ & -0.58 \\
$1985-93$ & +0.31 \\
\hline
\end{tabular}

and Orobie Groups, AAR levels that clearly indicate negative balances (Pelfini and Smiraglia, 1996).

\section{THE 20TH-GENTURY GLIMATIC TREND IN LOMBARDY}

The rapid retreat of the Lombard glaciers in the course of the 20th century is attributable to negative mass balances originating from temperature increases or reductions in snow accumulation (or from both factors). The purpose of this research was to verify whether the Lombard glaciers supplied significant signs of the warming phenomenon in progress at the global level and at the regional level. As to the entity of the warming phenomenon in Lombardy, there are conflicting opinions among researchers, owing also to the utilisation of different meteorological stations for the data analyzed and to the varying time periods covered by the historical series of meteorological data taken into consideration. This study adopted only one station as reference, Sondrio, situated in a large longitudinal Alpine valley. The data set covers the period 1915-93 and includes mean summer (June-September) temperatures. The data are expressed as deviations of the decadal mean temperatures from their overall summer mean and are shown in Table 2 and Figure 5.

In the Sondrio data set, at least four main phases are distinguishable: (1) 1914-24, cold phase; (2) 1925-54, warm phase with a higher mean summer temperature than the 1915-93 mean by $0.57^{\circ} \mathrm{C}$, a genuine thermic optimum; (3) 1955-84, cold phase $\left(-0.60^{\circ} \mathrm{C}\right)$; (4) 1985-93, warm phase. In summary, it can be said that the first half of the 20 th

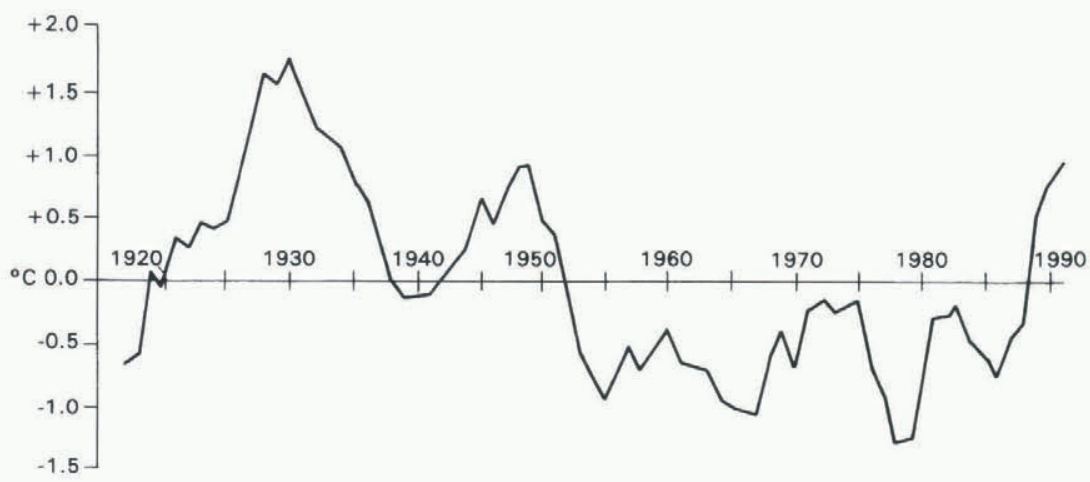

Fig. 5. Deviations of mean annual summer temperatures at Sondrio station from their overall mean (1915-93: $\left.19.9^{\circ} \mathrm{C}\right)(5 \mathrm{year}$ running means). 
century (1915-54) was $0.76^{\circ} \mathrm{C}$ warmer than the second half (1955-93) and that the warmest decade was 1925-34.

\section{GONGLUSIONS}

The Lombard glaciers have been undergoing intensive areal reduction and retreating since the start of the 20th century, and they are responding to the slight temperature increase that took place in Lombardy and which brought about the end of the Little Ice Age. According to Pelfini (1995), the increase in the mean annual temperature in the OrtlesCevedale Group since the Little Ice Age is about $0.5^{\circ} \mathrm{C}$, and the equilibrium-line altitude is $102 \mathrm{~m}$ higher. Signs of the four temperature phases identified for the 20th century are manifested by the Lombard glaciers in very different manners. For the cold phase in the second decade, there are only a few uncertain signals from the surveys (but this may be partly due to the poor quality of and gaps in monitoring data). The other three phases are reflected with clear signs and extension. More specifically, the 1955-84 cold phase could be linked with the advance of the fronts indicated above. With the beginning of the cold phase established as occurring in the early 1950s, the positive response of the fronts of the main Lombard glaciers took place between 1967 and 1981 and, on an average of nine glaciers, in 1973, i.e. about 20 years later. This does not conflict with the geometric features of the glaciers considered, nor with data on the glacier dynamics. According to Jóhannesson and others (1989), Paterson (1994) and Haeberli and Hoelzle (1995), the response time can be roughly estimated as the ratio between the maximum thickness of the glacier and the negative balance on the front. In the case of the Forni glacier, for which the data available are thorough, the maximum thickness is about $100 \mathrm{~m}$, whereas annual ablation in the terminal sector is $4-5 \mathrm{~m}$. Therefore, the theoretical response time would be $20-25$ years. Yet, it must be noted that the response to the subsequent warming phase was much more rapid, and for some glaciers almost immediate. The resumption of the frontal retreat can be determined as occurring in 1984 on average, and as late as 1990 only for the Ventina glacier.

The Lombard glaciers can be considered as valid indica- tors of 20th-century temperature trends; they provide clear signals of the warming phenomenon in progress and, above all, they confirm global trends that have already been identified (Haeberli and others, 1989), particularly the slowingdown of the recession and the phase reversal in the second half of the century (at least until the mid-1980s) (Patzelt, 1985; Wood, 1988). Thus, they too may be considered key parameters for monitoring the climatic system in Italy.

\section{REFERENCES}

Barsanti, M. and C. Smiraglia. 1994. Alpine glaciers as indicators of climatic environmental fluctuations in progress: the example of the Ghiacciaio della Sforzellina. In First International Conference "Man and Mountain '94", Ponte di Legno, Italy. Proceedings, 61-75.

Barsanti, M., M. Pelfini and C. Smiraglia. 1996. Glacier mass balance: some results from central Italian Alps. Z Gletscherkd. Glazialgeol., 31, Part 1, 1995, $149-157$.

Comitato Glaciologico Italiano. 1961. Catasto dei ghiacciai italiani. Ghiacciai della Lombardia e dell'Ortles-Cevedale. Vol. III. Torino, Comitato Glaciologico Italiano.

Galluccio, A. and G. Catasta. 1992. Ghiacciai in Lombardia - nuovo catasto dei ghiaccia Lombardi. Milan, Servizio Glaciologico Lombardo.

Haeberli, W. 1990. Glacier and permafrost signals of 20th-century warming. Ann. Glaciol., 14, 99-101.

Haeberli, W. and M. Hoelzle. 1995. Application of inventory data for estimating characteristics of and regional climate-change effects on mountain glaciers: a pilot study with the European Alps. Ann. Glaciol., 21, $206-212$.

Haeberli, W., P. Müller, P. Alean and H. Bösch. 1989. Glacier changes following the Little Ice Age - a survey of the international data basis and its perspectives. In Oerlemans, J., ed. Glacier fluctuations and climatic change. Dordrecht, etc., Kluwer Academic Publishers, 77-101.

Jóhannesson, T., C. Raymond and E. Waddington. 1989. Time-scale for adjustment of glaciers to changes in mass balance. f. Glaciol., 35(121), 355-369.

Paterson, W. S. B. 1994. The physics of glaciers. Third edition. Oxford, etc., Elsevier

Patzelt, G. 1985. The period of glacier advances in the Alps, 1965 to 1980 . Z Gletscherkd. Glazialgeol., 21, 403-407.

Pelfini, M. 1995. Equilibrium line altitude (ELA) variations recorded by Ortles-Cevedale glaciers (Lombardy, Italy) from Little Ice Age to present. Geogr. Fis. Din. Quat., 17 (2), 1994, 197-206.

Pelfini, M. and C. Smiraglia. 1992. Recent fluctuations of glaciers in Valtellina (Italian Alps) and climatic variations. f. Glaciol., 38(129), 309-313.

Pelfini, M. and C. Smiraglia. 1996. Fattore AAR (Accumulation Area Ratio), variazioni frontali e relazioni con il clima sui ghiacciai delle Alpi Lombarde. Geogr. Fís. Din. Quat., 18(1), 1995, 47-56.

Porro, C. 1925. Elenco dei ghiacciai italiani. Parma, Ufficio Idrografico del Po.

Wood, F. B. 1988. Global alpine glacier trends, 1960s to 1980s. Arct. Alp. Res., $20(4), 404-413$. 